\title{
Glutaraldehyde Release from Heat-Polymerized Acrylic Resins after Disinfection and Chemical and Mechanical Polishing
}

\author{
Iara Augusta ORSI ${ }^{1}$ \\ Vanessa Gomes ANDRADE ${ }^{2}$ \\ Pierina Sueli BONATO ${ }^{3}$ \\ Lariça Barbosa RAIMUNDO ${ }^{1}$ \\ Daniella Silva HERZOG ${ }^{1}$ \\ Eduardo BORIE ${ }^{4}$ \\ ${ }^{1}$ Department of Dental Materials and Prosthodontic, Ribeirão Preto Dental School, \\ USP - University of São Paulo, Ribeirão Preto, SP, Brazil \\ ${ }^{2}$ Private Practice, São Sebastião do Paraíso, MG, Brazil \\ ${ }^{3}$ School of Pharmaceutical Sciences of Ribeirão Preto, USP - University of São Paulo, Ribeirão Preto, SP, Brazil \\ ${ }^{4}$ Integral Dentistry Department, Faculty of Medicine, Universidad de La Frontera, Temuco, Chile
}

\begin{abstract}
This study evaluated the release of glutaraldehyde from heat-polymerized acrylic resins subjected to disinfection followed by chemical and mechanical polishing. Ninety disc-shaped specimens (15 x $4 \mathrm{~mm}), 30$ per resin (Lucitone 550, QC-20 and Classico), were made and assigned to 2 groups according to the type of polishing. One side of each specimen was not polished and the other was either mechanically $(n=45)$ or chemically $(n=45)$ polished, and immersed in water at $50^{\circ} \mathrm{C}$ for $1 \mathrm{~h}$ to allow the release of intrinsic substances and then kept in distilled water for 7 days. The specimens were disinfected by immersion in $2 \%$ glutaraldehyde for 10 min. After this period, 3 specimens from each group were immersed in water for 15, 30, 60, 120 and 240 min. For the 15-, 30-, 60-min immersions, 4 water exchanges were done at the end of period. High performance liquid chromatography (HPLC) was used to detect and quantify the glutaraldehyde released after each period. Data were analyzed statistically by two-way ANOVA and multiple comparisons were done by Tukey's and Scheffé's tests $(\alpha=0.05)$. No glutaraldehyde release was observed from the specimens with chemical polishing at any of the immersion periods, while the mechanically polished specimens released glutaraldehyde. In the groups with water exchanges, Lucitone released more disinfectant in the $15-\mathrm{min}$ period $(0.040 \mu \mathrm{g} / \mathrm{mL})$, Classico in the $30-\mathrm{min}(0.021 \mu \mathrm{g} / \mathrm{mL})$ and $60-\mathrm{min}(0.018$ $\mu \mathrm{g} / \mathrm{mL})$ periods, and QC-20 the same amount $(-1.760 \mu \mathrm{g} / \mathrm{mL})$ in all periods. In the groups without water exchanges, Lucitone released the highest amount of disinfectant $(-1.370 \mu \mathrm{g} / \mathrm{mL})$, differing significantly from QC-20 $(0022 \mathrm{~g} / \mathrm{mL})$ and Classico $(0019 \mathrm{~g} / \mathrm{mL})$, which were similar. The findings of this showed that chemically polished specimens from the 3 resin brands did not release glutaraldehyde after different periods of immersion, while glutaraldehyde release was observed from the mechanically polished specimens, especially from those made of Lucitone resin.
\end{abstract}

Key Words: Disinfection, acrylic resin, liquid chromatography, polishing.

\section{INTRODUCTION}

Chemical disinfection of prosthetic materials has been an effective procedure to avoid cross-contamination among dentists, patients, assistants and technicians in the dental prosthetic laboratory. However acrylic resins adsorb water and consequently disinfecting solutions. These solutions can later be released in the saliva, as demonstrated by Mähönen et al. (1), who observed the presence of disinfecting solutions in saliva after denture disinfection procedures using $2 \%$ glutaraldehyde.

In dental clinic, glutaraldehyde is routinely used diluted to $1: 5$ or $1: 10$ with immersion times of 10 to 90 $\min (2)$. This substance provides an intermediate level of disinfection and acts damaging the proteins and nucleic acids of the microorganisms, ultimately leading to their destruction (3).

There are several advantages of using

Correspondence: Profa. Dra. Iara A. Orsi, Departamento de Materiais Dentários e Prótese, Faculdade de Odontologia de Ribeirão Preto, USP, Avenida do Café S/N, Monte Alegre, 14040-904 Ribeirão Preto, SP, Brasil. Tel: +55-16-3602-4796. Fax: +55-16-3602-4780. e-mail: iaraorsi@forp.usp.br 
glutaraldehyde instead of other disinfecting solutions, namely its capacity of penetrating blood and exudates because of its low surface tension, thus reaching the surface to be disinfected more easily (3), and its minimal corrosion potential on metal surfaces (2).

Glutaraldehyde is widely used for disinfecting endoscopes, which require a high level of disinfection to prevent the transmission of pathogenic microorganisms, is recommended by the American Association for Professionals in Infection Control and Epidemiology (APIC) and Food and Drug Administration (FDA) because it has a high level of disinfection and does not cause damage to equipment (4). Care must be taken in handling and using this substance because direct exposure may produce cutaneous and mucosal inflammation (5) and handling in locations without proper ventilation may cause asthma and respiratory sensitivity of the operator (6). The inadvertent contact of glutaraldehyde in the colon mucosa may cause colitis (7). Glutaraldehyde release from colonoscopy and endoscopy equipment after disinfection has been widely described (8).

Currently, the use of glutaraldehyde is prohibited in several countries. However considering its efficacy in denture disinfection, the operator's exposure is minimal (8). The period recommended is between 10 to $20 \mathrm{~min}$, and the dentures are immersed in glutaraldehyde in a hermetic and perfectly closed receptacle.

Due to concern about the presence of residual glutaraldehyde in endoscopes and colonoscopes after disinfection, manual and automatic cleaning methods have been developed to achieve the release of chemical residues present in these devices after disinfection (9). Farina et al. (10) determined the levels of residual glutaraldehyde in endoscopes and colonoscopes after disinfection and compared manual and automatic cleaning methods. Glutaraldehyde concentration was determined by high performance liquid chromatography (HPLC) and the parameters for this analysis were based on the analytical method of Menet et al. (11), which consisted of glutaraldehyde determination after reacting with 2.4-dinitrophenylhydrazine.

Considering that gastroenterological devices, adsorb disinfectants due to their porous structure, they can be compared to the acrylic resins. As denture base resin adsorb water and oral fluids, it can be assumed that they also adsorb disinfecting solutions, which may be released later in the saliva, causing allergic and/or inflammatory reactions.
The review of the literature reveals only studies assessing the release of formaldehyde and residual methacrylate monomer from acrylic resins in saliva and water (12-15) and there is no information referring to the release of disinfecting solutions. The aim of this study was to evaluate the release of glutaraldehyde from 3 commercial brands of heat-polymerized acrylic resin subjected to mechanical or chemical polishing after disinfection. The hypothesis of this study was that acrylic resins with mechanical and chemical polishing release glutaraldehyde after chemical disinfection.

\section{MATERIAL AND METHODS}

A rectangular metal matrix, with a central opening of $15 \mathrm{~mm}$ diameter $\mathrm{x} 4 \mathrm{~mm}$ height, was used to make wax patterns (Wilson; Polidental Manufacturing and Trade Ltd., São Paulo, SP, Brazil). These wax patterns were invested in flasks with dental stone (Gesso Rio, Rio Claro, SP, Brazil), which was coated with a thin layer of sodium alginate (Cel-Lac; SS White Dental Products, Rio de Janeiro, RJ, Brazil). The monomer and polymer of the heat-polymerized acrylic resins Clássico, Lucitone 550 and QC-20 (Table 1) were dispensed, mixed, packed, and pressed into the flask following the respective manufacturers' instructions. Lucitone 550 and Clássico are conventional heat-polymerized resins and QC-20 is a dual-polymerizing acrylic resin that uses thermal and chemical activators and is classified as a quick-polymerizing resin.

After resin polymerization, the flasks were cooled at room temperature before opening. The disc-shaped resin specimens were then deflasked. Ninety specimens were fabricated, 30 from each brand of resin, divided into 2 groups depending on the type of polishing (mechanical and chemical). Sample grouping and specimen distribution are illustrated in Figure 1. Excess of acrylic resin were removed with tungsten steel burs (\#1508; Edenta, Schweiz, Switzerland) at low speed with additional hand smoothing with \#320-grit silicon carbide paper (Norton Manufacturing and Trade Ltd., Guarulhos, SP, Brazil) using water as a coolant.

In order to simulate a complete denture, one side of the resin specimen was polished and the other surface was not. The non-polished side did not receive any further surface treatment in addition to the $\# 320$-grit silicon carbide paper hand smoothing; the polished side received addition polishing with \#400- and 600-grift silicon carbide papers. Mechanical polishing was done 
with a horizontal machine (Struers DPU-10; Panambra, São Paulo, SP, Brazil) using a rag wheel with polishing pastes (pumice/water followed by zinc oxide/water).

Specimens subjected to chemical polishing were processed in a chemical polishing machine (PQ 9000; Termotron Ltd., Piracicaba, SP, Brazil) by soaking them in a methyl methacrylate-based solution (Poli-Quim; Clássico Dental Products, São Paulo, SP, Brazil) at approximately $80^{\circ} \mathrm{C}$ for $10 \mathrm{~s}$, and then placing them on a glass plate to dry.

All specimens were stored in water at $50^{\circ} \mathrm{C}$ for $1 \mathrm{~h}$, with the purpose of releasing intrinsic substances such as methyl methacrylate and formaldehyde (14). After this, specimens were stored in distilled water at room temperature for 7 days before disinfection and application of the HPLC.

The mechanically and chemically polished specimens were immersed in $2 \%$ alkaline glutaraldehyde (Glutesin 28; Probem Laboratory of Pharmaceutical and Dental Products, Catanduva, SP, Brazil) for $10 \mathrm{~min}$. Later, each specimen was thoroughly washed with 80 $\mathrm{mL}$ of distilled water, dried with absorbent paper and placed in a glass receptacle containing $15 \mathrm{~mL}$ of water that was previously purified by the milli-Q system (Milli-Q Plus CPMQ 0004R1; Millipore Manufacturing and Trade Ltd., São Paulo, SP, Brazil) and kept immersed for $15,30,60,120$ and $240 \mathrm{~min}$. After these periods, each sample was removed from the water and this water was analyzed by HPLC.

In the 15-, 30- and 60-min groups, up to 4 changes of water were made after each period to avoid saturation of the water by the disinfectant released. After the first immersion in water, each specimen was dried with absorbent paper and immersed in a different glass receptacle containing $15 \mathrm{~mL}$ of water, purified by the milli-Q system (Millipore Manufacturing and Trade Ltd.), in their respective time. This process was repeated successively until the last of a total of 4 water exchanges had been made (Fig. 1).

HPLC was used to detect and quantify the amount of glutaraldehyde released from each specimen. In order to determine the presence of glutaraldehyde, it was necessary to perform glutaraldehyde derivation with 2,4-dinitrophenylhydrazine (DNPH); that is, the reactive product between glutaraldehyde and the DNPH was detected $(10,15)$. The DNPH solution (Merck Chemical Industry, Rio de Janeiro, RJ, Brazil), was prepared in acetonitrile at a concentration of $0.2 \%(\mathrm{~m} / \mathrm{v})$.

Successive dilutions of $25 \%$ glutaraldehyde (Merck Chemical Industry) were made to obtain a solution with $1 \mu \mathrm{g} / \mathrm{mL}$ concentration. This working solution was used to prepare the calibration curve

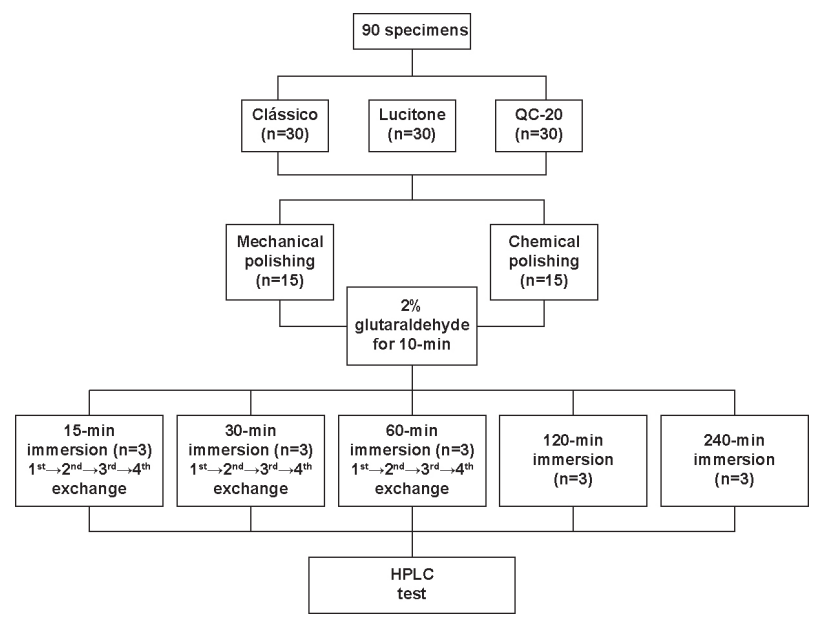

Figure 1. Flowchart of sample grouping and specimen distribution.

Table 1. Heat-polymerized acrylic resins.

\begin{tabular}{|c|c|c|c|}
\hline \multirow{2}{*}{$\begin{array}{l}\text { Acrylic } \\
\text { resins }\end{array}$} & \multicolumn{2}{|c|}{ Principle Ingredients } & \multirow{2}{*}{ Manufacturer } \\
\hline & Polymer & Monomer & \\
\hline Lucitone 550 & $\begin{array}{l}\text { Copolymer methyl-n-butyl methacrylate, } \\
\text { benzoyl peroxide, mineral dyes }\end{array}$ & $\begin{array}{c}\text { Methyl methacrylate, ethylene } \\
\text { glycol, dimethacrylate, } \\
\text { hydroquinone }\end{array}$ & $\begin{array}{l}\text { Dentsply International Inc., } \\
\text { York, PA, USA }\end{array}$ \\
\hline Classico & $\begin{array}{l}\text { Polymethylmethacrylate, ethylacrylate, } \\
\text { benzoyl peroxide, organic pigments }\end{array}$ & $\begin{array}{c}\text { Methyl methacrylate, topanol } \\
\text { stabilizer }\end{array}$ & $\begin{array}{l}\text { Classico Ind. e Com. Ltda., } \\
\text { São Paulo, SP, Brazil. }\end{array}$ \\
\hline QC-20 & $\begin{array}{c}\text { Copolymer methyl-n-butyl methacrylate, } \\
\text { benzoyl } \\
\text { peroxide, mineral dyes }\end{array}$ & $\begin{array}{l}\text { Methylmethacrylate, ethylene } \\
\text { glycol, dimethacrylate, } \\
\text { N,N dimethyl-p-toluidine, } \\
\text { hydroquinone methyl ether }\end{array}$ & $\begin{array}{c}\text { Dentsply International Inc., } \\
\text { York, PA, USA }\end{array}$ \\
\hline
\end{tabular}


solutions $(0.25,0.5$ and $1.0 \mathrm{mg} / \mathrm{L})$, allowing calculation of the concentration of glutaraldehyde in each specimen.

Solutions were prepared with $1 \mathrm{~mL}$ of the water used for immersion of the specimens, adding $500 \mu \mathrm{L}$ of DNPH solution, $50 \mu \mathrm{L}$ of hydrochloric acid at $50 \%$ $(\mathrm{m} / \mathrm{V})$ and $200 \mu \mathrm{L}$ of water. These prepared solutions were taken to an ultrasound (Ultra Sonic Cleaner; Unique Manufacturing and Trade of Electronics Products, Santo Amaro, SP, Brazil) for 10 min to allow homogenization and removal of the air bubbles. Later the solutions were immersed in a bath (BM. EV.; EVLAB- Manufacturing and Trade of Laboratory Products, Londrina, PR, Brazil) at $45^{\circ} \mathrm{C}$ for $75 \mathrm{~min}$ (14). After this period, 50 $\mu \mathrm{L}$ were subjected to HPLC analysis. During handling, preparation, and even during HPLC analysis, the solutions were protected from light and the test tubes with the solutions were properly sealed.

Preliminary statistical analysis showed that the sample distribution was normal and homogeneous, thus allowing the use of the parametric tests two-way ANOVA and Tukey's and Scheffé tests $(\alpha=0.05)$.

\section{RESULTS}

The chromatographic analysis of water specimens from each specimen of the 3 brands of acrylic resin that were subjected to chemical polishing revealed no detectable release of glutaraldehyde in all immersion periods. On the other hand, there was glutaraldehyde release at concentrations up to $0.06059 \mu \mathrm{g} / \mathrm{mL}$ from specimens subjected to mechanical polishing.

Comparing the resins, it was observed that specimens with immersion without water exchange showed the highest release from Lucitone $(0.043725 \mu \mathrm{g} / \mathrm{mL})(\mathrm{p}<0.05)$ compared with QC-20 $(0.028444 \mu \mathrm{g} /$ $\mathrm{mL})$ and Clássico $(0.027781 \mu \mathrm{g} / \mathrm{mL})$, which did not differ significantly from each other.

Statistical analysis of each resin brand with mechanical polishing revealed significant differences $(\mathrm{p}<0.01)$ between Lucitone and Clássico resins during the immersion time. Tukey's test for immersion time showed statistically significant differences under all periods for Lucitone resins. Clássico resin showed no differences between 30- and 60-min times (Table 2). There were statistically significant differences for individual factors of water exchange (Lucitone and Clássico, $\mathrm{p}<0.01$ and $\mathrm{QC}-20, \mathrm{p}<0.05$ ).

Tukey's and Scheffé tests for Lucitone revealed no differences between the third and fourth water exchanges, with a high amount of glutaraldehyde in the first water exchange. For Clássico, there were statistically significant differences $(\mathrm{p}<0.01)$ between the first water exchange and the combination of the second, third and fourth water exchanges. For QC-20, the second water exchange was in an intermediate position between the first and the combination of the third/fourth water exchanges (Table 3).

In addition, significant difference $(p<0.01)$ was found for the interaction of immersion time and water exchange. For Lucitone, the highest reduction of glutaraldehyde release was observed in the third water exchange at $30 \mathrm{~min}$ immersion time (Fig. 2). For Clássico, the 15-min immersion period in the third water exchange showed the highest reduction in the amount of glutaraldehyde released (Fig. 3). For QC-20, the third water exchange in the 15-min and 60-min immersion periods showed the lowest values for presence of glutaraldehyde (Fig. 4).

Table 2. Means $(\mu \mathrm{g} / \mathrm{mL})$ according to the immersion periods.

\begin{tabular}{lccc}
\hline $\begin{array}{l}\text { Immersion } \\
\text { period }\end{array}$ & Clássico & Lucitone & QC-20 \\
\hline $15 \mathrm{~min}$ & $0.0138 \pm 0.004 \mathrm{a}$ & $0.0395 \pm 0.011 \mathrm{c}$ & $0.0174 \pm 0.004 \mathrm{f}$ \\
$30 \mathrm{~min}$ & $0.0209 \pm 0.004 \mathrm{~b}$ & $0.0265 \pm 0.012 \mathrm{~d}$ & $0.0182 \pm 0.006 \mathrm{f}$ \\
$60 \mathrm{~min}$ & $0.0179 \pm 0.007 \mathrm{~b}$ & $0.0309 \pm 0.011 \mathrm{e}$ & $0.0183 \pm 0.006 \mathrm{f}$ \\
\hline
\end{tabular}

Different letters indicate statistically significant difference at 5\% (Tukey's test).

Table 3. Means ( $\mu \mathrm{g} / \mathrm{mL})$ according to the water exchanges.

\begin{tabular}{lccc}
\hline $\begin{array}{l}\text { Water } \\
\text { exchange }\end{array}$ & Clássico & Lucitone & QC-20 \\
\hline 1st & $0.0258 \pm 0.005 \mathrm{a}$ & $0.0485 \pm 0.006 \mathrm{c}$ & $0.0223 \pm 0.008 \mathrm{f}$ \\
2nd & $0.0159 \pm 0.004 \mathrm{~b}$ & $0.0347 \pm 0.007 \mathrm{~d}$ & $0.0173 \pm 0.004 \mathrm{~g}$ \\
3rd & $0.0145 \pm 0.004 \mathrm{~b}$ & $0.0199 \pm 0.009 \mathrm{e}$ & $0.0145 \pm 0.003 \mathrm{~h}$ \\
4th & $0.0140 \pm 0.002 \mathrm{~b}$ & $0.0260 \pm 0.013 \mathrm{e}$ & $0.0153 \pm 0.002 \mathrm{~h}$ \\
\hline
\end{tabular}

Different letters indicate statistically significant difference at 5\% (Tukey's and Scheffé tests). 


\section{DISCUSSION}

Inflammatory reactions in the oral mucosa are commonly observed in patients that use their dentures continuously. Several compounds including residual monomer, methyl methacrylate and other additives, such as hydroquinone, benzoyl peroxide, N,N-dimethylp-toluidine, formaldehyde (formed from residual monomer) are released from the acrylic polymers, spread into saliva and come into contact with the oral mucosa, causing flushing and a burning sensation in the adjacent areas (13). A similar behavior can be observed with chemical disinfectants. In order to choose the correct disinfectant, several factors need to be considered; risk of toxicity to the patient or professional, potential instrument damage, stability, antimicrobial activity, ability to inactivate the microorganisms rapidly, and cost (17), among other.

The biological factors that provide the sterilizing properties can also be the responsible for the allergenic properties. Therefore, not using glutaraldehyde as a sterilizing agent because of its toxicity is not a solution.

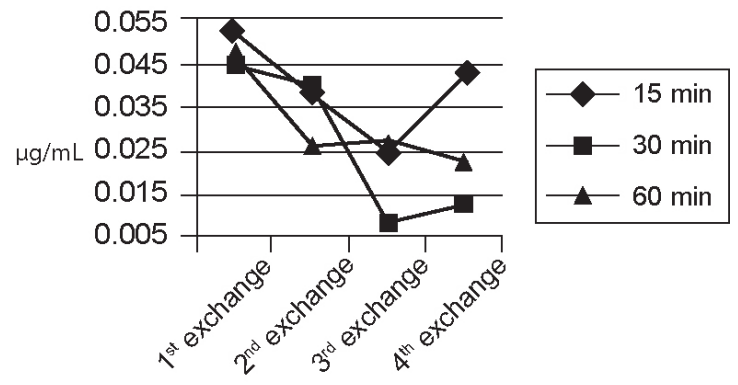

Figure 2. Graphic presentation of the interaction exchange $\mathrm{x}$ immersion period for Lucitone.

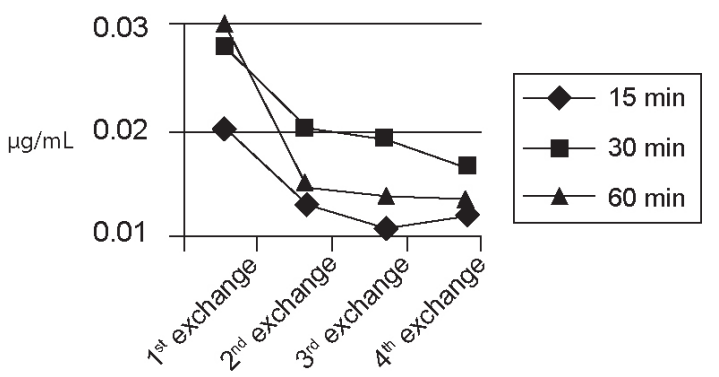

Figure 3. Graphic presentation of the interaction exchange $\mathrm{x}$ immersion period for Clássico.
It is necessary to establish a protocol to eliminate the residues of disinfectant after disinfection. The toxicity of glutaraldehyde depends on the contact period and its concentration. Its cytotoxic effect increases with the increase of the exposure time (18).

For all resins, the specimens that received chemical polishing did not release glutaraldehyde after disinfection at any time. These results may be due to fact that surface finishing was achieved with methyl methacrylate-based substances, leading to the formation of a film that covered the resin surface, rendering waterproof and preventing penetration of liquids (19). Thus, rinsing in running water can be sufficient to remove all disinfectant residues, as it remains only on the surface.

On other hand, all specimens that received mechanical polishing released glutaraldehyde after disinfection. This can be explained by the presence of unsealed pores on the surface of the acrylic resin, causing the adsorption of substances and their subsequent release.

The analysis of the water in which the specimens were immersed for different periods $(15,30,60,120$ and $240 \mathrm{~min}$ ) in glutaraldehyde showed no statistically significant differences among periods and for the interaction immersion periods $\mathrm{x}$ resins. This can be justified by saturation of water with disinfectant because if the water is already saturated after $15 \mathrm{~min}$, saturation is expected in all other periods as well.

Water exchanges were proposed in this study to prevent the saturated water from precluding further release of disinfectant from the resin. This way, all adsorbed disinfectant was expected to be released because immersion of the resin specimens in clean water would allow the disinfectant to be leached until a saturation point was reached again. Water exchanges were performed only in the 15-, 30- and 60-min

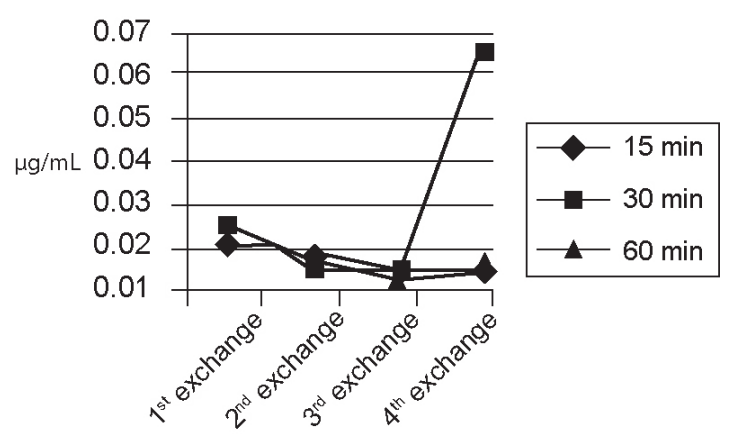

Figure 4. Graphic presentation of the interaction exchange $\mathrm{x}$ immersion period for QC-20. 
subgroups because changing the water after shorter periods of immersion would influence glutaraldehyde release more rapidly. Moreover, longer immersion periods, such as 120 and $240 \mathrm{~min}$, are not feasible in clinical and laboratory practice because patients would have to wait for long periods to receive their dentures.

As far as the immersion periods are concerned, Lucitone and Clássico differed significantly from each other. For Lucitone, more glutaraldehyde was released in the shortest water immersion period (15 min), while for Clássico the greatest release occurred in the 30and 60-min periods. For QC-20, the same amount of glutaraldehyde release occurred in all periods. These results could be attributed to the chemical composition, polymerization reaction and internal porosity of the resins in addition to the capacity of each resin to adsorb water and disinfecting solutions. The three commercial brands of resins are different in their composition, polymerization reaction and probably in their porosity, being this last the most important property that could be related with the adsorption of liquids, as noted in a previous study on flexural strength (19).

There is concern that denture immersion in chemical solutions used for cleaning and disinfection could lead to the absorption of these solutions with subsequent release in the saliva. In the present in vitro study, there was difference in glutaraldehyde release from the three commercial brands of denture base acrylic resins when subjected to mechanical polishing. However, no glutaraldehyde release from the same resins was observed when they were subjected to chemical polishing. Further trials are needed to test the action of other disinfectants on physical and mechanical properties of acrylic resins.

\section{RESUMO}

Este estudo determinou a liberação de glutaraldeído de resinas acrílicas termopolimerizáveis submetidas a polimento químico e mecânico e desinfetadas. Noventa corpos-de-prova circulares (15 x $4 \mathrm{~mm}$ ), 30 de cada tipo de resina (Lucitone, QC-20 e Clássico), foram confeccionados e divididos em 2 grupos referentes ao tipo de polimento. Um dos lados de cada corpo-de-prova não foi polido e o outro foi polido mecanicamente $(n=45)$ ou quimicamente $(\mathrm{n}=45)$, e imersos em água aquecida a $50^{\circ} \mathrm{C}$ por $1 \mathrm{~h}$ para liberação de substâncias intrínsecas e mantidos em água destilada por 7 dias. A seguir era realizada a desinfecção por imersão em solução de glutaraldeído a $2 \%$ por $10 \mathrm{~min}$. Decorrido este período, três corpos-de-prova de cada grupo eram imersos em água por 15 , 30, 60, 120 e $240 \mathrm{~min}$. Nos períodos de 15, 30 e $60 \mathrm{~min}$ foram realizadas até 4 trocas de água após cada período. As amostras eram analisadas por meio de cromatografia líquida de alta eficiência (HPLC) após cada período. Os dados foram analisados estatisticamente pela Análise de Variância e testes complementares de Tukey e Scheffé $(\alpha=0,05)$. Os corpos-de-prova com polimento químico, de todas as marcas comerciais de resina, não liberaram glutaraldeído em qualquer um dos períodos de imersão em água, enquanto os com polimento mecânico liberaram. Nos grupos com trocas de água, a resina Lucitone liberou maior quantidade de desinfetante nas trocas de $15 \min (0,040 \mu \mathrm{g} / \mathrm{mL})$, a resina Clássico nas de $30(0,021 \mu \mathrm{g} / \mathrm{mL})$ e $60 \min (0,018 \mu \mathrm{g} / \mathrm{mL})$ e a QC-20 liberou a mesma quantidade $(-1,760 \mu \mathrm{g} / \mathrm{mL})$, em todos os períodos de imersão em água. Nos grupos sem trocas de água, a resina Lucitone liberou maior quantidade de desinfetante $(-1,370$ $\mu \mathrm{g} / \mathrm{mL})$, sendo diferente estatisticamente das resinas QC-20 $(0,022 \mu \mathrm{g} / \mathrm{mL})$ e Clássico $(0,019 \mu \mathrm{g} / \mathrm{mL})$, que são similares. Pelos resultados conclui-se que corpos-de-prova polidos quimicamente, das três marcas comerciais de resina, não liberaram glutaraldeído após os diferentes períodos de imersão. Contudo, nos corpos-deprova polidos mecanicamente houve liberação do desinfetante, com Lucitone liberando maior quantidade em relação às demais resinas estudadas.

\section{ACKNOWLEDGEMENTS}

Financial support for this study was provided by scientific research grant \#00/11515-1 from the São Paulo State Research Foundation (FAPESP).

\section{REFERENCES}

1. Mähönen K, Virtanen K, Larmas M. The effect of prosthesis disinfection on salivary microbial levels. J Oral Rehabil 1998;25:304-310.

2. Naylor WP. Infection control in fixed prosthodontics. Dent Clin North Am 1992;36:809-831.

3. Molinari JA, Runnells RR. Role of disinfectants in infection control. Dent Clin North Am 1991;35:323-337.

4. Rutala WA, Weber DJ. Guideline for disinfection and sterilization in healthcare facilities, 2008. Available from: http://www.cdc.gov/ ncidod/dhap/pdf/guidelines /Disinfection_nov_2008.pdf.Acessed July 2, 2010.

5. Hanson JM, Plusa SM, Bennett MK, Browell DA, Cunliffe WJ. Glutaraldehyde as a possible cause of diarrhea after sigmoidoscopy. Br J Surg 1998;85:1385-1387.

6. Ahishali E, Uygur-Bayramiçli O, Dolapçioğlu C, Dabak R, Mengi A, Işik A, et al.. Chemical colitis due glutaraldehyde: case series and review of the literature. Dig Dis Sci 2009;54:2541-2545.

7. Dietze B, Neumann H, Mansmann U, Martiny H. Determination of glutaraldehyde residues on flexible endoscopes after chemothermal treatment in an endoscope washer-disinfector. Endoscopy 2001;33:529-532.

8. Lerones C, Mariscal A, Carnero M, García-Rodríguez A, Fernández-Crehuet J. Assessing the residual antibacterial activity of clinical materials disinfected with glutaraldehyde, o-phthalaldehyde, hydrogen peroxide or 2-bromo-2-nitro-1,3propanediol by means of a bacterial toxicity assay. Clin Microbiol Infect 2004;10:984-989.

9. Greenwald D. Reducing infection risk in colonoscopy. Colonoscopy Gastrointest Endoscopy Clin N Am 2010;20:603614.

10. Farina A, Fievet MH, Plassart F, Menet MC, Thuillier A. Residual glutaraldehyde levels in fiberoptic endoscopes: measurement and 
implications for patient toxicity. J Hosp Infect 1999;43:293-297.

11. Menet MC, Gueylard D, Fievet MH, Thuillier A. Fast specific separation of bactericidal and sporicidal aldehydes by highperformance liquid chromatography: example of glutaraldehyde determination. J Chromatogr 1997;692:79-86.

12. Ruyter IE. Release of formaldehyde from denture base polymers. Acta Odontol Scand 1980;38:17-27.

13. Koda T, Tsuchiya H, Yamauchi M, Ohtani S, Takagi N, Kawano J. Leachablity of denture-base acrylic resins in artificial saliva. Dent Mater 1990;6:13-16.

14. Tsuchiya H, Hoshino Y, Tajima K, Takagi N. Leaching and cytotoxicity of formaldehyde and methyl methacrylate from acrylic resin denture base materials. J Prosthet Dent 1994;71:618624.

15. Kedjarune U, Charoenworaluk N, Koontongkaew S. Release of methyl methacrylate from heat-cured and autopolymerized resins: cytotoxicity testing related to residual monomer. Aust Dent J 1999;44:25-30.
16. Selim S. Determination of residues of karbutilate and its major metabolites in water, soil, and grass by high-pressure liquid chromatography. J Agric Food Chem 1977;25:567-572.

17. Angelillo IF, Bianco A, Nobile CG, Pavia M. Evaluation of the efficacy of glutaraldehyde and peroxygen for disinfection of dental instruments. Lett Appl Microbiol 1998;27:292-296.

18. Wen SH, Feigal RJ, Messer HH. Cytoxicity of glutaraldehyde and formaldehyde in relation to time of exposure and concentration. Pediatr Dent 1990;12:303-307.

19. Orsi IA, Andrade VG. Effect of chemical disinfectants on the transverse strength of heat-polymerized acrylic resins subjected to mechanical and chemical polishing. J Prosthet Dent 2004;92:382388.

Received July 14, 2010

Accepted March 27, 2011 